\title{
DAMPAK FAKTOR-FAKTOR KINERJA (LEVERAGE, PERTUMBUHAN, PAJAK, ASET BERWUJUD) TERHADAP KINERJA KEUANGAN PADA CV. TUMARIMA INDONESIA TAHUN 2018
}

\author{
Endang Naryono
}

\section{STIE Pasim Sukabumi}

correspondence can be addressed to: endang@stiepasim.ac.id

Received: 15.05 .2020

Revised: 15.06 .2020

Accepted: 29.06.2020

\section{Abstract}

Company performance is a description of the financial condition of a company which is analyzed by means of financial analysis, so that it can be seen about the good and bad financial condition of a company that reflects the work performance in a certain period. This study aims to analyze the effect of performance factors (leverage, growth, taxes, tangible assets) simultaneously and partially on financial performance at CV. Tumarima Indonesia in 2018. This type of research is an associative descriptive study with primary and secondary supporting data with a quantitative approach. Researchers use this design to analyze performance factors (leverage, growth, taxes, tangible assets) on financial performance at CV. Tumarima Indonesia. Sources of data are taken from respondents and from company documentation. The types of data in this study are primary and secondary, primary data is taken by questionnaire while secondary is taken from documentation. The variables studied were Leverage (X1), Growth (X2), Tax (X3), Tangible Assets (X4) and the dependent variable (Y), namely financial performance. To determine the simultaneous effect using the F test, to determine the partial effect using the t test and to determine the dominant effect using the beta coefficient. The results showed that there was a simultaneous effect of independent variables on the dependent variable. There is a partially significant influence variable Leverage (X1), Growth (X2), Tangible Assets (X4) on financial performance at CV. Tumarima Indonesia in 2018 while the Tax variable (X3) has no effect. Leverage variable is the independent variable which dominantly affects the dependent variable, namely financial performance at CV. Tumarima Indonesia in 2018.

\section{Keywords: Leverage, Growth, Taxes, Tangible Assets, Financial Performance}

\section{PENDAHULUAN}

Tujuan utama didirikannya suatu perusahaan adalah untuk optimalisasi nilai atau add value, keuntungan, dan kesejahteraan pemegang saham atau perusahaan. Oleh karena itu profitabilitas perusahaan telah menjadi kriteria utama dalam menentukan kinerja keuangan. Pada dunia bisnis profitabilitas memainkan peran penting dalam struktur dan pengembangan perusahaan karena dapat mengukur kinerja dan keberhasilan perusahaan. Pengukuran kinerja perusahaan juga dapat dilihat dari laporan keuangan perusahaan. Rasio keuangan dapat digunakan sebagai alat dalam melakukan analisis kinerja keuangan perusahaan, salah satu rasio yang digunakan 
sebagai pengukuran kinerja keuangan yaitu rasio profitabilitas, dimana ROA merupakan salah satu cara yang digunakan dalam pengukuran tersebut.

Kinerja perusahaan merupakan suatu gambaran tentang kondisi keuangan suatu perusahaan yang dianalisis dengan alat-alat analisis keuangan, sehingga dapat diketahui mengenai baik buruknya keadaan keuangan suatu perusahaan yang mencerminkan prestasi kerja dalam periode tertentu. Kinerja keuangan itu sendiri ialah tingkat prestasi atau hasil nyata yang dicapai kadang-kadang dipergunakan untuk memperoleh suatu hasil yang postif. Kinerja juga didefinisikan keberhasilan personel dalam mewujudkan sasaran strategik di empat perspektif : keuangan, costumer, proses, serta pembelajaran dan pertumbuhan [1], untuk dapat memperoleh gambaran tentang kinerja keuangan perlu mengadakan interprestasi atau analisa terhadap data keuangan yang tercermin dalam laporan keuangan.

Perkembangan bisnis perumahan khususnya di Kota Sukabumi sangat menarik minat para pengusaha untuk menanamkan investasinya ke dalam usaha bisnis perumahan. Para pengusaha menilai bahwa usaha bisnis perumahan merupakan salah satu sektor usaha yang mempunyai prospek bagus ke depan dan mampu memberikan return yang maksimal terhadap investasinya. Hal ini dapat dilihat dari semakin meningkatnya konsumen ingin memiliki perumahan sebagaimana yang disediakan CV. Tumarima Indonesia. Besarnya peluang pasar yang dipandang menjanjikan bagi perkembangan usaha Perumahan ini juga alasan mengapa para pengusaha tertarik untuk melakukan investasi di usaha Perumahan.

Dipilihnya CV. Tumarima Indonesia sebagai objek penelitian adalah karena perkembangan usaha Perumahan ini semakin meningkat pesat, banyaknya kebiasaan perumahan masyarakat Sukabumi ditandai dengan semakin banyaknya usaha perumahan yang bermunculan dengan beragam jenis dan tawaran perumahan khas mereka. Melihat perkembangan usaha perumahan di wilayah Kota Sukabumi tersebut memberikan peluang bagi para pengusaha perumahan untuk melakukan investasi di bidang usaha perumahan ini. Industri perumahan khususnya di daerah Kota Sukabumi sekarang sangat potensial perkembangannya, karena besarnya minat masyarakat Sukabumi untuk bermukim di perumahan.

\section{LANDASAN TEORI DAN KERANGKA KONSEPTUAL}

\section{Konsep Kinerja Perusahaan}

Kinerja perusahaan merupakan suatu gambaran tentang kondisi keuangan suatu perusahaan yang dianalisis dengan alat-alat analisis keuangan, sehingga dapat diketahui mengenai baik buruknya keadaan keuangan suatu perusahaan yang mencerminkan prestasi kerja dalam periode tertentu. Memon dkk. [2] menyatakan kinerja adalah kualitas dari setiap 
perusahaan yang dapat dicapai dengan hasil yang membanggakan. Sebagai contoh, sebuah perusahaan yang memiliki pendapatan yang tinggi atas aset (ROA) dikatakan berkinerja baik.

Menurut Fahmi [3] kinerja keuangan adalah suatu analisis yang dilakukan untuk melihat sejauh mana suatu perusahaan telah melaksanakan dengan menggunakan aturan-aturan pelaksanaan keuangan secara baik dan benar. Untuk melihat kondisi kinerja perusahaan ada tiga rasio keuangan yang paling dominan yang dijadikan rujukan bagi investor yaitu rasio likuiditas, rasio solvabilitas, dan rasio profitabilitas. Di balik berbagai nama yang mencakup beragam teknik, analisis data memiliki beberapa pendekatan dan aspek [4]. Laporan keuangan dapat dijadikan sebagai alat untuk mengukur kinerja perusahaan, terdapat dua metode yang digunakan dalam perbandingan hasil dari perhitungan pada laporan keuangan, yaitu :

1) Time series analysis

Yaitu membandingkan secara antar waktu atau antar periode, dengan tujaun itu nantinya akan terlihat secara grafik.

\section{2) Cross Sectional Approach}

Yaitu melakukan perbandingan terhadap hasil hitungan rasio- rasio yang telah dilakukan antara satu perusahaan dan perusahaan lainnya dalam runag lingkup yang sejenis yang dilakukan secara bersamaan.

Riyanto [5] menyebut istilah ROA dengan net earning power ratio (rate of return on investment/ROI) yaitu kemampuan dari modal yang diinvestasikan dalam keseluruhan aktiva untuk menghasilkan keuntungan neto. Keuntungan neto yang dimaksud adalah keuntungan neto sesudah pajak. Memon dan Tahir [6] menyatakan bahwa rasio keuangan sangat membantu dan alat yang dapat memudahkan untuk mengidentifikasi kelemahan dan kekuatan (kinerja) dari setiap perusahaan dengan melihat laporan keuangan perusahaan. Rasio keuangan sangat penting gunanya untuk melakukan analisa terhadap kondisi keuangan perusahaan. Bagi investor jangka pendek dan menengah pada umumnya lebih banyak tertarik kepada kondisi keuangan jangka pendek dan kemampuan perusahaan untuk membayar dividen yang memadai. Secara jangka panjang rasio keuangan juga dipakai dan dijadikan sebagai acuan dalam menganalisis kinerja suatu perusahaan. Untuk mengukur kinerja perusahaan digunakan return on assets [7].

Return on Asset (ROA) merupakan rasio yang terpenting di antara rasio profitabilitas yang ada. Return on assets juga mengukur keefektifan manajemen dalam menghasilkan laba dengan aset yang tersedia, ROA juga disebut ROI (return on investment) semakin tinggi pengembalian perusahaan atas total aset semakin baik. 


\section{Konsep Leverage}

Di dalam manajemen keuangan perusahaan pada umumnya dikenal dua macam leverage, yaitu operating leverage dan financial leverage. Operating leverage dapat digambarkan secara mudah dengan menggunakan laporan rugi laba. Leverage ini membandingkan pengaruh pedapatan (penjualan) terhadap perubahan keuntungan operasional (Operating Income). Jika kita ingin menerapkan proses produksi baru dengan mesin-mesin baru yang mahal dan canggih. Sebagai konsekuensi perusahaan akan mengeluarkan uang yang banyak demi mesin tersebut dan akan berdampak pada menurunya keuntungan operasional akan tetapi penggunaan mesin baru akan menghemat beberapa variabel. Contoh dengan mesin baru yang berkerja lebih cepat tenaga manusia bisa dikurangi. Perusahaan akan lebih menghemat daripada mempertahankan mesin lama. Tentu saja kedua cara tersebut harus memperhitungkan derajat dari pengungkit operasioanl atau degree of operational leverage (dol).

Operating leverage menurut Hanafi [8] bisa diartikan sebagai seberapa besar perusahaan menggunakan beban tetap operasional. Beban tetap operasional biasanya berasal dari biaya depresiasi, biaya produksi dan pemasaran yang bersifat tetap (misalnya gaji bulanan karyawan). Sebagai kebalikannya adalah beban (biaya) variabel operasional. Contoh biaya variabel operasional adalah biaya tenaga kerja yang dibayar berdasarkan produk yang dihasilkan (misalnya karyawan harian perusahaan rokok, dibayar Rp.100,00 untuk setiap rokok yang dilinting). Komposisi biaya tetap/variabel yang berbeda mempunyai implikasi yang berbeda terhadap risiko dan keuntungan yang diharapkan oleh perusahaan.

Adapun kegunaan dari operating leverage adalah leverage operasi dapat mengukur perubahan pendapatan atau penjualan terhadap keuntungan operasi perusahaan. Dilihat dari kegunaan operating leverage, dapat disimpulkan bahwa perusahaan dapat mengetahui perubahan laba operasi sebagai akibat perubahan penjualan, sehingga perusahaan dapat mengetahui keuntungan operasi perusahaan. Operating leverage dapat digambarkan secara mudah dengan menggunakan laporan rugi laba. Leverage ini membandingkan pengaruh pedapatan (penjualan) terhadap perubahan keuntungan operasional (Operating Income). Salah satu alasan mengapa begitu banyak orang yang tertarik untuk trading forex dibandingkan dengan instrumen keuangan lainnya adalah bahwa dengan forex, Anda biasanya bisa mendapatkan leverage lebih tinggi dari yang biasa Anda dapat dengan saham [9].

\section{Konsep Pertumbuhan Perusahaan}

Salah satu faktor yang menentukan struktur modal perusahaan adalah pertumbuhan perusahaan [10]. Hal ini dilihat bahwa perusahaan yang tumbuh membutuhkan dana didalam 
menjalankan aktivitas operasinya. Pertumbuhan perusahaan ini mencakup pertumbuhan penjualan, laba, dan aktiva. Pertumbuhan perusahaan ini dilihat dengan semakin tinggi tingkat pertumbuhan suatu perusahaan maka semakin baik juga perusahaan tersebut. Salah satu pengukuran pertumbuhan perusahaan adalah penjualan. Hal ini dapat dilihat melalui peningkatan penjualan perusahaan dari satu periode ke periode berikutnya. Adanya peningkatan penjualan maka akan terjadi juga peningkatan atas laba yang diperoleh.

Pertumbuhan menurut Beaver, Ketter, dan Scholes [11] didefinisikan sebagai perubahan tahunan dari total aktiva. Perubahan tersebut dilihat melalui peningkatan aktiva perusahaan dari setiap periodenya. Peningkatan aktiva tersebut menyebabkan perusahaan membutuhkan dana yang besar. Karena kebutuhan dana semakin besar maka perusahaan cenderung menahan sebagian besar pendapatannya. Semakin besar pendapatan yang ditahan menyebabkan semakin kecil deviden yang dibagikan kepada pemegang saham.

Disamping itu, Kallapur dan Trombley [12] menjelaskan bahwa pertumbuhan perusahaan merupakan kemampuan perusahaan untuk meningkatkan ukuran perusahaan melalui peningkatan aktiva. Tingkat pertumbuhan yang semakin cepat mengindikasikan bahwa perusahaan sedang mengadakan ekspansi. Kegagalan yang disebabkan oleh ekspansi akan meningkatkan beban perusahaan karena perusahaan harus menutup pengembalian beban ekspansi. Hal ini menyebabkan pembagian dividen kepada pemegang saham menurun. Kondisi tersebut dapat menyebabkan investor tidak berminat lagi untuk menanamkan modalnya pada perusahaan sehingga cenderung akan menjual saham yang dimilikinya.

Brigham dan Houston [13] mendefinisikan pertumbuhan sebagai perubahan aset tahunan dari total aktiva. Hal ini dapat dibuktikan melalui perusahaan yang tumbuh dapat dilihat dari peningkatan aktiva untuk memperbesar ukuran perusahaan. Konsep ini didasarkan pada dua argumentasi Pertama, pertumbuhan aktiva berbeda dengan pertumbuhan penjualan yang setiap usaha yang dilakukan secara langsung membawa implikasi pada penerimaan. Pertumbuhan aktiva mencerminkan waktu yang lebih panjang dari pertumbuhan penjualan. Kedua, investasi pada aktiva membutuhkan waktu sebelum dioperasikan, sehingga aktifitas yang dilakukan tidak terkait dengan penerimaan [14].

Disamping itu perusahaan yang tumbuh cenderung memiliki leverage dan kebijakan dividen yang lebih rendah dibandingkan perusahaan tidak tumbuh [15]. Karena perusahaan yang tumbuh memerlukan banyak dana untuk meningkatkan pertumbuhannya dibandingkan membayar dividen. Sedangkan menurut Porter [16] menyatakan bahwa perusahaan yang tumbuh memiliki pertumbuhan laba dan penjualan yang tinggi.

Penelitian yang dilakukan Hartono dan Sulistiawan [17], menunjukkan bahwa 
pertumbuhan aset perusahaan merupakan suatu harapan yang diinginkan oleh pihak internal perusahaan yaitu manajemen maupun eksternal perusahaan seperti investor dan kreditor. Pertumbuhan ini diharapkan dapat memberikan aspek yang positif bagi perusahaan seperti adanya suatu kesempatan berinvestasi di perusahaan tersebut. Prospek perusahaan yang tumbuh bagi investor merupakan suatu prospek yang menguntungkan, karena investasi yang ditanamkan diharapkan akan memberikan return yang tinggi. Sejalan dengan Penelitian yang dilakukan Vogt [18] menunjukkan bahwa perusahaan yang bertumbuh akan direspon positif oleh pasar.

Disamping itu Porter [16] merumuskan bahwa perusahaan yang tumbuh merupakan perusahaan yang memiliki pertumbuhan margin, laba dan penjualan yang tinggi. Kallapur dan Trombley [19] juga menyatakan bahwa pertumbuhan laba pada perusahaan yang tumbuh lebih besar dibandingkan pada perusahaan tidak tumbuh, karena kesempatan investasi pada periode berikutnya semakin besar.

Smith dan Watts [20], menyatakan bahwa potensi pertumbuhan suatu perusahaan akan mempengaruhi kebijakan yang dibuat oleh perusahaan (seperti kebijakan pendanaan, dividen, dan kompensasi). Hal ini dapat dibuktikan pada perusahaan yang berpotensi untuk tumbuh mempunyai rasio debt to equity yang lebih rendah daripada perusahaan yang tidak tumbuh. Kecenderungan perusahaan mempunyai rasio debt to equity yang rendah dilakukan untuk mengurangi masalah agensi yang potensial berasosiasi dengan eksistensi hutang yang berisiko dalam struktur modal [21].

\section{Konsep Pajak}

Fahmi [3] menyatakan pajak merupakan kewajiban perusahaan yang harus selalu dibayar kepada pihak yang berkepentingan, yang kemudian pendapatan dari pembayaran pajak tersebut dipakai untuk meningkatkan kesejahteraan rakyat, apabila perolehan laba (profitabilitas) wajib pajak semakin besar maka pembayaran pajak akan semakin besar, sehingga kontribusi kepada pendapatan negara juga semakin besar. Keuntungan dari adanya hutang terhadap pembayaran pajak penghasilan adalah bahwa pembayaran bunga dapat dikurangkan sebagai beban. Pembayaran bunga ini mengurangi pajak, sedangkan laba yang ditahan dikaitkan dengan saham tidak dapat dikurangkan oleh perusahaan dalam perhitungan pajaknya. Bunga adalah beban yang dapat dikurangkan untuk tujuan perpajakan (deductible expense), dan pengurang pajak adalah hal yang penting bagi perusahaan yang terkena tarif pajak yang tinggi. Oleh karena itu semakin tinggi tarif pajak sebuah perusahaan maka semakin besar manfaat yang diperoleh dari penggunaan utang. 


\section{(1) Subjek Pajak}

\section{a. Subjek Pajak Penghasilan}

Yang menjadi subjek pajak penghasilan adalah:

a) Orang pribadi;

b) Warisan yang belum terbagi sebagai satu kesatuan menggantikan yang berhak;

c) Badan;

Adalah sekumpulan orang dan/atau modal yang merupakan kesatuan baik yang melakukan usaha maupun yang tidak melakukan usaha yang meliputi perseroan terbatas, perseroan komanditer, perseroan lainnya, badan usaha milik negara atau badan usaha milik daerah dengan nama dan dalam bentuk apa pun, firma, kongsi, koperasi, dana pensiun, persekutuan, perkumpulan, yayasan, organisasi massa, organisasi sosial politik, atau organisasi lainnya, lembaga dan bentuk badan lainnya termasuk kontrak investasi kolektif dan bentuk usaha tetap

d) Bentuk usaha tetap.

b. Subjek Pajak Dalam Negeri

Subjek Pajak dalam negeri adalah:

a) Orang pribadi yang bertempat tinggal di Indonesia, orang pribadi yang berada di Indonesia lebih dari 183 hari dalam jangka waktu 12 bulan, atau orang pribadi yang dalam suatu tahun pajak berada di Indonesia dan mempunyai niat untuk bertempat tinggal di Indonesia; Kewajiban pajak subjektif orang pribadi dimulai pada saat orang pribadi tersebut dilahirkan, berada, atau berniat untuk bertempat tinggal di Indonesia dan berakhir pada saat meninggal dunia atau meninggalkan Indonesia untuk selama-lamanya.

b) Badan yang didirikan atau bertempat kedudukan di Indonesia, kecuali unit tertentu dari badan pemerintah

Kewajiban pajak subyektif badan dimulai pada saat badan tersebut didirikan atau bertempat kedudukan di Indonesia dan berakhir pada saat dibubarkan atau tidak lagi bertempat kedudukan di Indonesia.

c)Warisan yang belum terbagi sebagai satu kesatuan menggantikan yang berhak.

Kewajiban pajak subyektif warisan yang belum terbagi dimulai pada saat timbulnya warisan yang belum terbagi tersebut dan berakhir pada saat warisan tersebut selesai dibagi.

(2) Objek Pajak

Yang menjadi objek pajak adalah penghasilan, yaitu setiap tambahan kemampuan ekonomis yang diterima atau diperoleh Wajib Pajak, baik yang berasal dari Indonesia 
maupun dari luar Indonesia, yang dapat dipakai untuk konsumsi atau untuk menambah kekayaan Wajib Pajak yang bersangkutan, dengan nama dan dalam bentuk apa pun, termasuk:

a. Penggantian atau imbalan berkenaan dengan pekerjaan atau jasa yang diterima atau diperoleh termasuk gaji, upah, tunjangan, honorarium, komisi, bonus, gratifikasi, uang pensiun, atau imbalan dalam bentuk lainnya, kecuali ditentukan lain dalam Undangundang ini;

b. Hadiah dari undian atau pekerjaan atau kegiatan, dan penghargaan;

c. Laba usaha;

d. Keuntungan karena penjualan atau karena pengalihan harta termasuk :

a) Keuntungan karena pengalihan harta kepada perseroan, persekutuan, dan badan lainnya sebagai pengganti saham atau penyertaan modal

b) Keuntungan karena pengalihan harta kepada pemegang saham, sekutu, atau anggota yang diperoleh perseroan, persekutuan, dan badan lainnya

c) Keuntungan karena likuidasi, penggabungan, peleburan, pemekaran, pemecahan, pengambilalihan usaha, atau reorganisasi dengan nama dan dalam bentuk apa pun;

d) Keuntungan karena pengalihan harta berupa hibah, bantuan, atau sumbangan, kecuali yang diberikan kepada keluarga sedarah dalam garis keturunan lurus satu derajat dan badan keagamaan, badan pendidikan, badan sosial termasuk yayasan, koperasi, atau orang pribadi yang menjalankan usaha mikro dan kecil, yang ketentuannya diatur lebih lanjut dengan Peraturan Menteri Keuangan, sepanjang tidak ada hubungan dengan usaha, pekerjaan, kepemilikan, atau penguasaan di antara pihak-pihak yang bersangkutan; dan

e) Keuntungan karena penjualan atau pengalihan sebagian atau seluruh hak penambangan, tanda turut serta dalam pembiayaan, atau permodalan dalam perusahaan pertambangan

Dalam hal terjadi pengalihan harta perusahaan kepada pegawainya, maka keuntungan berupa selisih antara harga pasar harta tersebut dengan nilai sisa buku merupakan penghasilan bagi perusahaan.

e. Penerimaan kembali pembayaran pajak yang telah dibebankan sebagai biaya dan pembayaran tambahan pengembalian pajak;

f. Bunga termasuk premium, diskonto, dan imbalan karena jaminan pengembalian utang;

g. Dividen, dengan nama dan dalam bentuk apapun, termasuk dividen dari perusahaan 
asuransi kepada pemegang polis, dan pembagian sisa hasil usaha koperasi;

h. Royalti atau imbalan atas penggunaan hak;

i. Sewa dan penghasilan lain sehubungan dengan penggunaan harta;

j. Penerimaan atau perolehan pembayaran berkala;

k. Keuntungan karena pembebasan utang, kecuali sampai dengan jumlah tertentu yang ditetapkan dengan Peraturan Pemerintah; Pembebasan utang oleh pihak yang berpiutang dianggap sebagai penghasilan bagi pihak yang semula berutang, sedangkan bagi pihak yang berpiutang dapat dibebankan sebagai biaya. Namun, dengan Peraturan Pemerintah dapat ditetapkan bahwa pembebasan utang debitur kecil misalnya Kredit Usaha Keluarga Prasejahtera (Kukesra), Kredit Usaha Tani (KUT), Kredit Usaha Rakyat (KUR), kredit untuk perumahan sangat sederhana, serta kredit kecil lainnya sampai dengan jumlah tertentu dikecualikan sebagai objek pajak.

1. Keuntungan selisih kurs mata uang asing; Keuntungan yang diperoleh karena fluktuasi kurs mata uang asing diakui berdasarkan sistem pembukuan yang dianut dan dilakukan secara taat asas sesuai dengan Standar Akuntansi Keuangan yang berlaku di Indonesia.

m. Selisih lebih karena penilaian kembali aktiva;

n. Premi asuransi, termasuk premi reasuransi;

o. Iuran yang diterima atau diperoleh perkumpulan dari anggotanya yang terdiri dari Wajib Pajak yang menjalankan usaha atau pekerjaan bebas;

p. Tambahan kekayaan neto yang berasal dari penghasilan yang belum dikenakan pajak;

q. Penghasilan dari usaha berbasis syariah; Kegiatan usaha berbasis syariah memiliki imbalan bunga; dan

r. Surplus Bank Indonesia.

Surplus Bank Indonesia yang merupakan objek Pajak Penghasilan adalah surplus Bank Indonesia menurut laporan keuangan audit setelah dilakukan penyesuaian atau koreksi fiskal sesuai dengan Undang-Undang Pajak Penghasilan dengan memperhatikan karakteristik Bank Indonesia bersifat konvensional. Namun, penghasilan yang diterima atau diperoleh dari kegiatan usaha berbasis syariah tersebut tetap merupakan objek pajak.

\section{Konsep Asset}

Aset adalah barang atau benda yang terdiri dari benda tidak bergerak dan benda bergerak baik yang berwujud (tangible) dan tidak berwujud (intangible) yang tercakup dalam 
aktiva/kekayaan perusahaan. Pengelolaan Aset (kekayaan) Perusahaan merupakan hal yang sangat penting karena untuk memantau dan menghitung serta memanfaatkannya secara optimal. Manajemen asset berfungsi untuk informasi perjalanan asset secara keseluruhan, memuat berapa banyak aset dan biayanya, pemanfaatan, kondisi dan pemeliharaan serta lokasi penyimpanan. Hal ini juga berfungsi untuk mencegah dari hilangnya asset, perhitungan pajak dan depresiasi.

Aset itu adalah nilai dari sesuatu yang dimiliki oleh perusahaan. Yang dapat dimasukkan ke dalam kolom asset salah satunya adalah gedung atau bangunan. Jadi kalau suatu perusahaan memiliki gedung senilai satu miliar rupiah, maka asset yang dihitung adalah satu miliar rupiah itu. Selain gedung, yang bisa dihitung sebagai asset bisa termasuk: merk dagang, paten teknologi, uang kas, mobil, dll.

Aset atau aktiva dipahami sebagai harta total. Namun biasanya untuk keperluan analisis dirinci menjadi beberapa kategori, seperti :
a. Aset lancar
b. Investasi jangka panjang
c. Aset tetap
d. Aset tidak berwujud
e. Aset pajak tangguhan
f. Aset lain

Daftar aset atau aktiva di dalam neraca disusun menurut tingkat likuiditasnya, mulai dari yang paling likuid hingga yang tidak likuid. Aktiva pada neraca disajikan pada sisi kiri secara berurutan dari atas ke bawah. Penyusunan neraca dimulai dari yang paling likuid (lancar), yaitu mulai dari aktiva lancar, aktiva tetap dan seterusnya. Komponen aktiva lancar menurut Kasmir [22] sebagai berikut: "kas, surat-surat berharga, piutang, persediaan, dan sebagainya". Komponen aktiva tetap menurut Kasmir [22] sebagai berikut: "Tanah, bangunan, mesin, kendaraan, peralatan, dan lainnya”. Berdasarkan teori diatas aktiva disusun secara berurutan dari mulai yang likuid sampai yang kurang likuid atau yang gampang dengan mudah diuangkan.

Bagi manajemen, di dalam membaca neraca, nilai aset perlu dicermati karena menjadi dasar pengukuran prestasi keuangan perusahaan. Ukuran ini menjadi pembanding prestasi sesuatu perusahaan dengan prestasi perusahaan yang lain dalam hal yang sama, apakah lebih baik atau tidak, sehingga dapat menjadi dasar keputusan manajemen untuk mempertahankan atau meningkatkannya.

Salah satu ukuran yang menyangkut aset atau aktiva adalah angka rasio penjualan/total 
aset, yang dinyatakan sebagai persentase. Asumsinya, semakin besar penjualan yang diwujudkan, semakin efisien penggunaan aset seluruhnya. Angka penjualan diambil dari laporan laba-rugi, sedang angka total aset berasal dari neraca. Dalam hal ini rasio dari tahun terakhir dibandingkan dengan tahun-tahun sebelumnya.

\section{Optimalisasi laba}

Ukuran yang lain menyangkut profitabilitas, yaitu angka laba harta atau laba investasi, yang berasal dari perbandingan angka laba (dipetik dari laporan laba rugi) dan total harta atau total aset, yang nilainya sama dengan istilah total investasi (dipetik dari neraca). Asumsinya, manajemen adalah penanggungjawab atas pemeliharaan dan pemanfaatan seluruh harta yang digunakan perusahaan, maka manajemen bertanggungjawab atas upaya optimalisasi laba yang dihasilkan dari seluruh harta itu. Penting bagi manajemen untuk melakukan analisis titik impas (BEP) sebagai alat studi kelayakan operasional perusahaan sehingga dapat melakukan evaluasi untuk optimalisasi laba [23].

\section{Pengaruh Leverage Terhadap Kinerja Keuangan}

Kinerja perusahaan dipengaruhi oleh beberapa faktor. Pada penelitian Zeitun dan Tian [24] menunjukkan bahwa leverage memiliki pengaruh negatif terhadap kinerja perusahaan, karena leverage yang tinggi menimbulkan konflik antara pemegang saham dan kreditur yang mengakibatkan terjadinya kenaikan suku bunga yang diberikan oleh kreditur, penambahan biaya pengawasan dan penurunan investasi. Jadi, konflik ini menunjukkan bahwa leverage yang tinggi menyebabkan kinerja yang buruk [25].

Faktor yang mempengaruhi kinerja keuangan antara lain leverage. Secara umum, semakin banyak utang perusahaan yang digunakan terkait total aset, semakin besar leverage keuangan perusahaan. Financial leverage adalah peningkatan risiko dan tingkat pengembalian melalui penggunaan pembiayaan tetap, seperti utang. Hutang jangka panjang memiliki pengaruh yang negatif terhadap kemampuan perusahaan dalam mendapatkan laba, hal ini menunjukkan bahwa perusahaan yang menggunakan hutang jangka panjang yang lebih tinggi memiliki profitabilitas yang lebih rendah, leverage dihitung dengan membagi total liabilities dengan total aset [26]. Margaretha dan Ramadhan [27] menyatakan total leverage dapat diukur total liabilities dibagi dengan total aset. Leverage yang tinggi juga menunjukkan kelemahan dari perusahaan yang mempunyai proporsi jumlah hutang. 


\section{Pengaruh Pertumbuhan, Terhadap Kinerja Keuangan}

Pertumbuhan mempengaruhi kinerja keuangan. Menurut Joni dan Lina [28] pertumbuhan aktiva menunjukkan besarnya dana yang dialokasikan oleh perusahaan ke dalam aktivanya. Pertumbuhan aktiva diukur dengan menghitung proporsi peningkatan total aktiva dari tahun sebelumnya dibandingkan dengan tahun berjalan. Perusahaan yang memiliki pertumbuhan tinggi akan membutuhkan dana yang lebih besar untuk melakukan investasinya dibandingkan dengan perusahaan yang memiliki pertumbuhan rendah. Pengukuran tingkat pertumbuhan dapat dilihat dari pertumbuhan total aset perusahaan. Aset juga merupakan aktiva yang digunakan untuk aktivitas operasional perusahaan. Semakin besar aset maka diharapkan semakin besar pula hasil operasional yang dihasilkan oleh suatu perusahaan. Peningkatan aset yang diikuti peningkatan hasil operasi akan semakin menambah kepercayaan pihak luar terhadap perusahaan, membuat pihak investor tertarik menanamkan dananya ke perusahaan serta semakin stabil tingkat penjualan mengakibatkan semakin stabil tingkat keuntungan yang diperoleh perusahaan, maka besar kemungkinan perusahaan mampu memenuhi kewajiban tetapnya. Perhitungan growth dapat dihitung dengan cara total aset sekarang dikurang dengan total aset tahun sebelumnya dibagi dengan total aset pada tahun sebelumnya [27].

\section{Pengaruh Pajak Terhadap Kinerja Keuangan}

Pajak mempengaruhi kinerja keuangan. Fahmi [3] menyatakan pajak merupakan kewajiban perusahaan yang harus selalu dibayar kepada pihak yang berkepentingan, yang kemudian pendapatan dari pembayaran pajak tersebut dipakai untuk meningkatkan kesejahteraan rakyat, apabila perolehan laba (profitabilitas) wajib pajak semakin besar maka pembayaran pajak akan semakin besar, sehingga kontribusi kepada pendapatan negara juga semakin besar. Keuntungan dari adanya hutang terhadap pembayaran pajak penghasilan adalah bahwa pembayaran bunga dapat dikurangkan sebagai beban. Pembayaran bunga ini mengurangi pajak, sedangkan laba yang ditahan dikaitkan dengan saham tidak dapat dikurangkan oleh perusahaan dalam perhitungan pajaknya. Bunga adalah beban yang dapat dikurangkan untuk tujuan perpajakan (deductible expense), dan pengurang pajak adalah hal yang penting bagi perusahaan yang terkena tarif pajak yang tinggi. Oleh karena itu semakin tinggi tarif pajak sebuah perusahaan maka semakin besar manfaat yang diperoleh dari penggunaan utang. Besarnya pajak juga memiliki hubungan positif dengan kinerja perusahaan, karena ketika perusahaan berkinerja baik dan rasio return on asset tinggi maka struktur modal mereka akan diarahkan secara optimal dan perusahaan akan membayar jumlah yang lebih tinggi 
dari pajak, hasil ini menunjukkan bahwa perusahaan dengan pembayaran pajak yang tinggi memiliki tingkat kinerja yang lebih tinggi [29].

\section{Pengaruh Aset Berwujud Terhadap Kinerja Keuangan}

Aset berwujud (tangibilitas) mempengaruhi kinerja keuangan. Menurut Rahardjo [30] aset berwujud atau fixed assets merupakan aktiva tetap berwujud yang diperoleh dalam bentuk siap pakai atau dengan dibangun terlebih dahulu, yang digunakan dalam operasi perusahaan, tidak dimaksudkan untuk dijual dalam rangka kegiatan normal perusahaan dan mempunyai masa manfaat lebih dari satu tahun. Aset ini berhubungan dengan mesin, bangunan, dan peralatan perusahaan. Dalam penelitiannya Akintoye [31] berpendapat bahwa perusahaan yang mempertahankan investasi besar dalam aset berwujud akan memiliki biaya lebih kecil.

\section{Kerangka Konseptual}

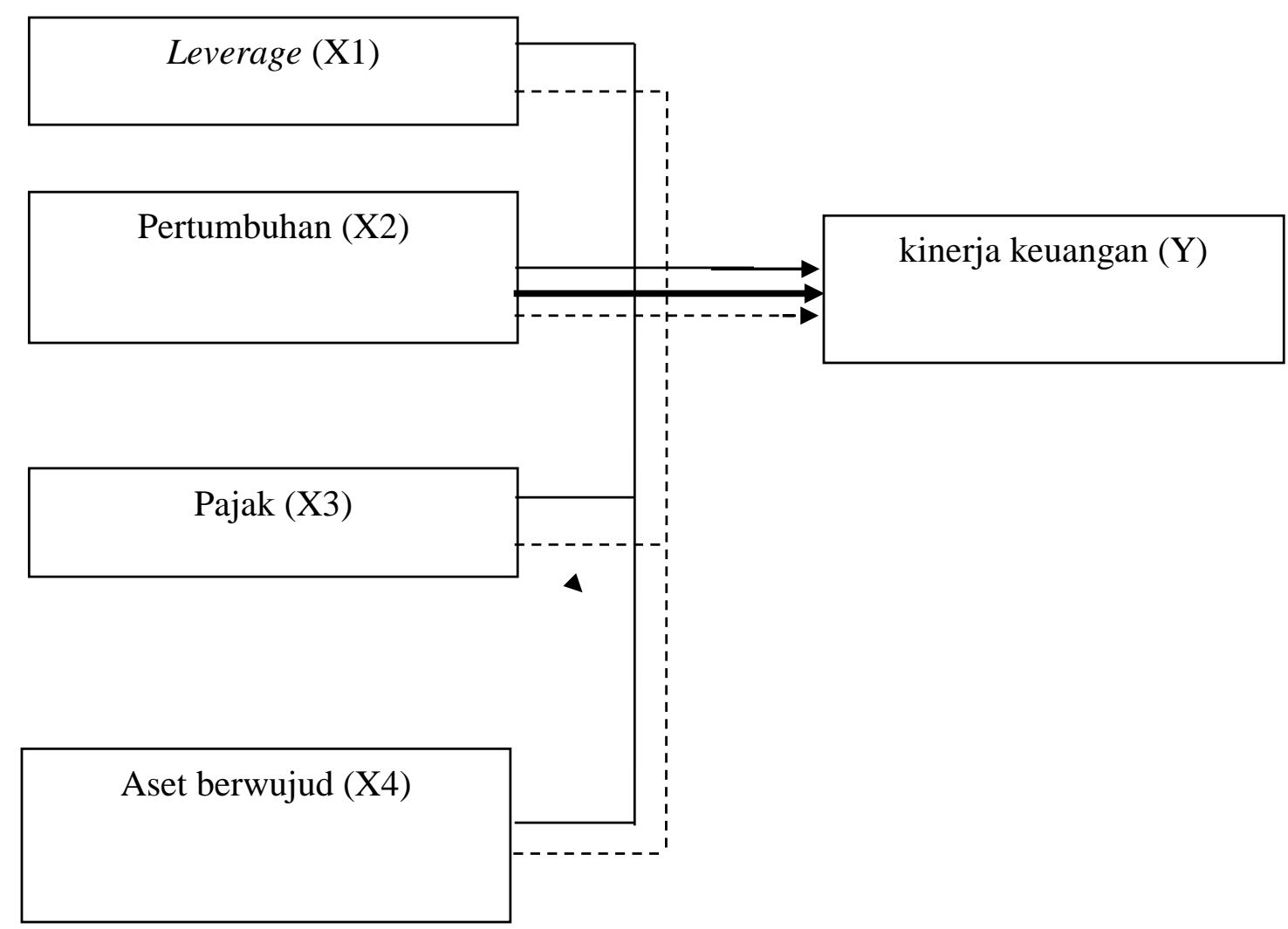

\section{METODOLOGI PENELITIAN}

\section{Desain Penelitian}

Jenis penelitian ini adalah studi kasus dengan pendekatan analisis regresi. Analisis regresi digunakan oleh peneliti, bila peneliti bermaksud meramalkan bagaimana keadaan (naik turunnya) variabel dependen (kriterium) [32]. Secara umum analisis regresi linier berganda pada dasarnya adalah studi mengenai ketergantungan variabel dependen (terikat) dengan satu 
atau lebih variabel independen (variabel penjelas / bebas), dengan tujuan untuk mengistemasi dan atau memprediksi rata-rata populasi atau nilai rata-rata variabel dependen berdasarkan nilai variabel independen yang diketahui [33].

Peneliti menggunakan desain ini untuk menganalisis Faktor-Faktor Kinerja (Leverage, Pertumbuhan, Pajak, Aset Berwujud) yang Memberikan Pengaruh Dominan Terhadap Kinerja Keuangan Pada CV. Tumarima Indonesia tahun 2018.

\section{Operasionalisasi Variabel}

Agar penelitian berjalan seperti apa yang dikehendaki, maka penulis akan menguraikan mengenai batasan dari variabel yang ada beserta pengukurannya. Adapun batasan dari variabel tersebut adalah sebagai berikut :

\section{Variabel Kinerja Perusahaan (Y)}

Kinerja perusahaan merupakan suatu gambaran tentang kondisi keuangan suatu perusahaan yang dianalisis dengan alat-alat analisis keuangan, sehingga dapat diketahui mengenai baik buruknya keadaan keuangan suatu perusahaan yang mencerminkan prestasi kerja dalam periode tertentu.Variabel ini dapat diukur dengan rumus :

Earning Available for Common stockholder

Total Assets

\section{Variabel Leverage (X1)}

Operating leverage dapat digambarkan secara mudah dengan menggunakan laporan rugi laba. Leverage ini membandingkan pengaruh pedapatan (penjualan) terhadap perubahan keuntungan operasional (Operating Income). Variabel ini dapat diukur dengan rumus:

Leverage $=\frac{\text { Total Liabilities }}{\text { Total Assets }}$

\section{Variabel Pertumbuhan Perusahaan (X2)}

Pertumbuhan menurut Beaver, Ketter, dan Scholes (1970) didefinisikan sebagai perubahan tahunan dari total aktiva. Perubahan tersebut dilihat melalui peningkatan aktiva perusahaan dari setiap periodenya. Peningkatan aktiva tersebut menyebabkan perusahaan membutuhkan dana yang besar. Karena kebutuhan dana semakin besar maka perusahaan cenderung menahan sebagian besar pendapatannya. Semakin besar pendapatan yang ditahan menyebabkan semakin kecil dividen yang dibagikan kepada pemegang saham. Variabel ini dapat diukur dengan rumus : 
$\frac{\text { total }_{\text {asset }}-\text { total asset }_{t 1}}{\text { total assets }}$

\section{Variabel Pajak (X3)}

Fahmi (2012) menyatakan pajak merupakan kewajiban perusahaan yang harus selalu dibayar kepada pihak yang berkepentingan, yang kemudian pendapatan dari pembayaran pajak tersebut dipakai untuk meningkatkan kesejahteraan rakyat, apabila perolehan laba (profitabilitas) wajib pajak semakin besar maka pembayaran pajak akan semakin besar, sehingga kontribusi kepada pendapatan negara juga semakin besar. Keuntungan dari adanya hutang terhadap pembayaran pajak penghasilan adalah bahwa pembayaran bunga dapat dikurangkan sebagai beban. Variabel ini dapat diukur dengan rumus :

Current Year's Tax

$\overline{\text { Earning Before Tax }}$

\section{Variabel Asset Berwujud (X4)}

Aset adalah barang atau benda yang terdiri dari benda tidak bergerak dan benda bergerak baik yang berwujud (tangible) dan tidak berwujud (intangible) yang tercakup dalam aktiva/kekayaan perusahaan. Pengelolaan Aset (kekayaan) Perusahaan merupakan hal yang sangat penting karena untuk memantau dan menghitung serta memanfaatkannya secara optimal. Variabel ini dapat diukur dengan rumus :

Fixed Assets

$\overline{\text { Total Assets }}$

\section{Teknik Pengumpulan dan Analisis Data}

Penulis memperoleh langsung data-data yang dibutuhkan berdasarkan dari informasi yang diberikan perusahaan melalui dokumentasi. Dalam penelitian, tema sosial ini telah ditetapkan secara spesifik oleh peneliti, yang selanjutnya disebut sebagai variabel penelitian. Penulis menggunakan metode dokumentasi untuk mendapatkan data perusahaan seperti latar belakang perusahaan dan layanan yang diberikan perusahaan. Teknik analisis yang digunakan dalam penelitian ini adalah sebagai berikut:

\section{Analisis kualitatif}

Analisis kualitatif adalah nilai dari perubahan-perubahan yang tidak dapat dinyatakan dalam angka, melainkan memberikan uraian-uraian sesuai dengan kenyataan dan keadaan yang sebenarnya yang terjadi pada obyek penelitian. 


\section{Analisis Kuantitatif}

Analisis kuantitatif adalah cara menganalisis data yang terbentuk angka dengan ukuran atau model. Untuk mengetahui pengaruh variabel bebas terhadap variabel terikat digunakan analisis statistika regresi linier berganda.

Persamaan regresi linier berganda yaitu sebagai berikut

$$
\mathrm{Y}=\mathrm{a}+\mathrm{b}_{1} \mathrm{X}_{1}+\mathrm{b}_{2} \mathrm{X}_{2}+\mathrm{b}_{3} \mathrm{X}_{3}+\mathrm{b}_{4} \mathrm{X}_{4}+\mathrm{e}
$$

Di mana:

$$
\begin{array}{ll}
\mathrm{Y} & =\text { Kinerja keuangan } \\
\mathrm{A} & =\text { Konstanta dari persamaan regresi } \\
\mathrm{b} 1, \mathrm{~b} 2, \mathrm{~b} 3, \mathrm{~b} 4 & =\text { Koefisien regresi } \\
\mathrm{X} 1 & =\text { Leverage } \\
\mathrm{X} 2 & =\text { Pertumbuhan } \\
\mathrm{X} 3 & =\text { Pajak } \\
\mathrm{X} 4 & =\text { Aset berwujud } \\
\mathrm{E} & =\text { Standard error }
\end{array}
$$

\begin{tabular}{|c|c|c|c|c|c|c|}
\hline \multirow{2}{*}{\multicolumn{2}{|c|}{ Model }} & \multicolumn{2}{|c|}{$\begin{array}{c}\text { Uns tandardized } \\
\text { Coefficients }\end{array}$} & \multirow{2}{*}{$\begin{array}{c}\begin{array}{c}\text { Standardi } \\
\text { zed } \\
\text { Coefficien } \\
\text { ts }\end{array} \\
\text { Beta } \\
\end{array}$} & \multirow[b]{2}{*}{$t$} & \multirow[b]{2}{*}{ Sig. } \\
\hline & & $\mathrm{B}$ & Std. Error & & & \\
\hline & (Constant) & 1.933 & .241 & & 8.034 & .510 \\
\hline & laverage (X1) & 1.864 & .209 & .348 & 6.552 & .007 \\
\hline & pertumbuhan (X2) & 1.764 & .197 & .332 & 6.138 & .010 \\
\hline & pajak (X3) & .261 & .069 & .051 & .622 & .562 \\
\hline & aset berwujud (X4) & .272 & .078 & .065 & .688 & .052 \\
\hline
\end{tabular}

\section{HASIL PENELITIAN DAN PEMBAHASAN}

Dalam penulisan skripsi ini digunakan cara regresi linier berganda. Analisis ini digunakan untuk mengetahui kontribusi variabel - variabel bebas terhadap variabel terikat. Adapun berdasarkan pengolahan data didapatkan hasil sebagai berikut :

\section{Tabel 1}

\section{Hasil Analisis Regresi Linier Berganda}

Coefficie nts

a. Dependent Variable: kinerja keuangan $(\mathrm{Y})$

Dalam penulisan skripsi ini digunakan cara regresi linier berganda. Analisis ini digunakan untuk mengetahui kontribusi variabel - variabel bebas terhadap variabel terikat. 
Berdasarkan analisa regresi linier berganda antara variabel bebas leverage (X1), pertumbuhan (X2), pajak (X3), dan aset berwujud (X4) terhadap kinerja keuangan pada CV. Tumarima Indonesia tahun 2018 (Y) maka dapat disusun persamaan sebagai berikut:

$\mathrm{Y}=1.933+1.864 \mathrm{X} 1+1.764 \mathrm{X} 2+0.261 \mathrm{X} 3+0.272 \mathrm{X} 4+\mathrm{e}$

Interpretasi :

Konstanta $(\mathrm{a})=1.933$ berarti variabel leverage $(\mathrm{X} 1)$, pertumbuhan $(\mathrm{X} 2)$, pajak $(\mathrm{X} 3)$, dan aset berwujud (X4) berpengaruh terhadap kinerja keuangan pada CV. Tumarima Indonesia (Y) sebesar 1.933. Artinya apabila variabel bebas sama dengan 0 maka diprekdisikan kinerja keuangan mengalami kenaikan sebesar 1.933

Koefisien regresi untuk leverage (X1) sebesar 1.864 berarti jika leverage mengalami kenaikan sebesar 1 satuan maka kinerja keuangan pada CV. Tumarima Indonesia (Y) akan mengalami peningkatan sebesar 1.864 dengan anggapan apabila variabel pertumbuhan (X2), pajak (X3) dan aset berwujud (X4) sama dengan 0 .

Koefisien regresi untuk pertumbuhan (X2) sebesar 1.764 berarti jika pertumbuhan mengalami kenaikan sebesar 1 satuan maka kinerja keuangan pada CV. Tumarima Indonesia (Y) akan mengalami peningkatan sebesar 1.764 apabila leverage (X1), pajak (X3), dan aset berwujud (X4) sama dengan 0.

Koefisien regresi untuk pajak (X3) sebesar 0.261 berarti jika pajak mengalami kenaikan sebesar 1 satuan maka kinerja keuangan pada CV. Tumarima Indonesia tahun 2018 (Y) tidak akan mengalami peningkatan sebesar 0.261. apabila leverage (X1), pertumbuhan (X2), dan aset berwujud (X4) sama dengan 0.

Koefisien regresi untuk aset berwujud (X4) sebesar 0.272 berarti jika aset berwujud mengalami kenaikan sebesar 1 satuan maka kinerja keuangan pada CV. Tumarima Indonesia (Y) tidak akan mengalami peningkatan sebesar 0.261. apabila leverage (X1), pertumbuhan (X2), dan pajak (X3) sama dengan 0 .

Analisis parsial (uji t) yaitu untuk mengetahui pengaruh dari masing - masing variabel bebas secara parsial atau individu terhadap variabel terikat digunakan uji t. Dalam tabel 4.2 disajikan hubungan regresi antara variabel bebas dengan variabel terikat dapat diuraikan sebagai berikut : 


\section{Tabel 2}

\section{Hasil Uji t}

Coefficients

\begin{tabular}{|c|c|c|c|c|c|c|}
\hline \multirow{2}{*}{\multicolumn{2}{|c|}{ Model }} & \multicolumn{2}{|c|}{$\begin{array}{c}\text { Uns tandardized } \\
\text { Coefficients }\end{array}$} & \multirow[t]{2}{*}{$\begin{array}{c}\begin{array}{c}\text { Standardi } \\
\text { zed } \\
\text { Coefficien } \\
\text { ts }\end{array} \\
\text { Beta } \\
\end{array}$} & \multirow[b]{2}{*}{$\mathrm{t}$} & \multirow[b]{2}{*}{ Sig. } \\
\hline & & $\mathrm{B}$ & Std. Error & & & \\
\hline & (Constant) & 1.933 & .241 & & 8.034 & .510 \\
\hline & laverage (X1) & 1.864 & .209 & .348 & 6.552 & .007 \\
\hline & pertumbuhan (X2) & 1.764 & .197 & .332 & 6.138 & .010 \\
\hline & pajak (X3) & .261 & .069 & .051 & .622 & .562 \\
\hline & aset berwujud (X4) & .272 & .078 & .065 & .688 & .052 \\
\hline
\end{tabular}

a. Dependent Variable: kinerja keuangan (Y)

1) Pengaruh secara parsial variabel leverage $\left(X_{1}\right)$ terhadap kinerja keuangan pada $C V$. Tumarima Indonesia tahun 2018 (Y).

Level of signifikan $=0.05$

Perhitungan yang didapat $\mathrm{t}$ hitung variabel leverage $\left(\mathrm{X}_{1}\right)$ sebesar $6.552>\mathrm{t}$ tabel sebesar 1.976 dan $\rho$. value $(0.007)<\alpha(0.05)$, maka $\mathrm{H} 1$ diterima dan $\mathrm{H} 0$ ditolak pada level of signifikansi 5\% sehingga secara parsial variabel leverage $\left(\mathrm{X}_{1}\right)$ berpengaruh terhadap kinerja keuangan CV. Tumarima Indonesia tahun 2018 (Y).

2) Pengaruh parsial pertumbuhan $\left(\mathrm{X}_{2}\right)$ terhadap kinerja keuangan pada $\mathrm{CV}$. Tumarima Indonesia tahun 2018 (Y).

Level of signifikan $=0.05$

Perhitungan yang didapat t hitung variabel pertumbuhan $\left(\mathrm{X}_{2}\right)$ sebesar $6.138>\mathrm{t}$ tabel sebesar 1.976 dan $\rho$. value $(0.010)<\alpha(0.05)$ maka H1 diterima dan H0 ditolak pada level of signifikansi $5 \%$ sehingga secara parsial variabel pertumbuhan $\left(\mathrm{X}_{2}\right)$ berpengaruh terhadap kinerja keuangan pada CV. Tumarima Indonesia (Y).

3) Pengaruh Parsial Variabel pajak $\left(\mathrm{X}_{3}\right)$ terhadap kinerja keuangan pada $\mathrm{CV}$. Tumarima Indonesia tahun 2018 (Y).

Level of signifikan $=0.05$

Perhitungan yang didapat $t$ hitung variabel pajak $\left(\mathrm{X}_{3}\right)$ sebesar $-0.622<\mathrm{t}$ tabel sebesar 1.976 dan $\rho$. value $(0.562)>\alpha(0.05)$, maka H0 diterima dan H1 ditolak pada level of signifikansi 5\% sehingga secara parsial variabel pajak tidak berpengaruh terhadap kinerja keuangan pada CV. Tumarima Indonesia tahun 2018 (Y).

4) Pengaruh parsial aset berwujud $\left(\mathrm{X}_{4}\right)$ terhadap kinerja keuangan pada $\mathrm{CV}$. Tumarima Indonesia tahun 2018 (Y). 
Level of signifikan $=0.05$

Perhitungan yang didapat t hitung variabel aset berwujud $\left(\mathrm{X}_{4}\right)$ sebesar $0.688<\mathrm{t}$ tabel sebesar 1.976 dan $\rho$. value $(0.052)<\alpha(0.05)$ maka H1 diterima dan H0 ditolak pada level of signifikansi 5\% sehingga secara parsial variabel aset berwujud $\left(\mathrm{X}_{4}\right)$ berpengaruh terhadap kinerja keuangan pada CV. Tumarima Indonesia tahun 2018 (Y).

Untuk mengetahui pengaruh dari variabel bebas secara simultan atau keseluruhan terhadap variabel terikat digunakan uji $\mathrm{F}$ dengan kriteria. Jika F hitung > F tabel, maka H0 ditolak dan H1 diterima yang berarti variabel bebas berpengaruh secara simultan terhadap variabel terikat. Hasil uji F sebagai berikut ;

\section{Tabel 3}

\section{Hasil Uji F}

ANOVA

\begin{tabular}{|c|c|c|c|c|c|c|}
\hline Model & & $\begin{array}{l}\text { Sum of } \\
\text { Squares }\end{array}$ & df & Mean Square & $\mathrm{F}$ & Sig. \\
\hline \multirow[t]{3}{*}{1} & Regression & .859 & 4 & .215 & 2.755 & $.047^{a}$ \\
\hline & Residual & 3.824E-02 & 3 & 1.275E-02 & & \\
\hline & Total & .897 & 7 & & & \\
\hline
\end{tabular}

a. Predictors: (Constant), aset berwujud $(X 4)$, laverage $(X 1)$, pajak $(X 3)$, pertumbuhan (X2)

b. Dependent Variable: kinerja keuangan $(\mathrm{Y})$

Jika F hitung $(2.755)>$ F tabel $(2.432)$ dan $\rho$. value $(0.047)<\alpha(0.05)$ maka H0 ditolak dan $\mathrm{H} 1$ diterima dengan tingkat signifikansi 0.049 yang berarti leverage (X1), pertumbuhan (X2), pajak (X3), asset berwujud (X4) memberikan pengaruh terhadap kinerja keuangan pada CV. Tumarima Indonesia tahun 2018 (Y).

Tabel 4

\section{Hasil Koefisien Determinasi $\left(\mathbf{R}^{2}\right)$}

Model Summary

\begin{tabular}{|l|r|r|r|r|}
\hline Model & $\mathrm{R}$ & $\mathrm{R}$ Square & $\begin{array}{c}\text { Adjusted } \\
\mathrm{R} \text { Square }\end{array}$ & $\begin{array}{r}\text { Std. Error of } \\
\text { the Estimate }\end{array}$ \\
\hline 1 & $.978^{\mathrm{a}}$ & .863 & .901 & .1129 \\
\hline
\end{tabular}

a. Predictors: (Constant), as et berwujud $(X 4)$, laverage $(X 1)$, pajak $(X 3)$, pertumbuhan $\left(X_{2}\right)$

Untuk mengetahui seberapa besar kontribusi keseluruhan dari variabel-variabel leverage (X1), pertumbuhan (X2), pajak (X3), asset berwujud memberikan pengaruh terhadap kinerja 
keuangan pada CV. Tumarima Indonesia tahun 2018 (Y) dapat dilihat dari nilai R Square yakni 0.863. Ini mengandung arti bahwa pengaruh leverage (X1), pertumbuhan (X2), pajak (X3), aset berwujud (X4) memberikan pengaruh terhadap kinerja keuangan pada CV. Tumarima Indonesia tahun 2018 (Y) sebesar 0.863 atau $86.3 \%$ sedangkan sisanya sebesar $13.7 \%$ dipengaruhi oleh variabel lain yang tidak masuk dalam penelitian ini.

\section{KESIMPULAN DAN SARAN}

\section{Kesimpulan}

1. Leverage (X1), pertumbuhan (X2), pajak (X3), asset berwujud (X4) memberikan pengaruh simultan terhadap kinerja keuangan pada CV. Tumarima Indonesia tahun 2018 (Y).

2. Secara parsial variabel leverage (X1) berpengaruh terhadap kinerja keuangan pada CV. Tumarima Indonesia tahun 2018 (Y).

3. Secara parsial variabel pertumbuhan (X2) berpengaruh terhadap kinerja keuangan pada CV. Tumarima Indonesia tahun 2018 (Y).

4. Secara parsial variabel pajak tidak berpengaruh terhadap kinerja keuangan pada CV. Tumarima Indonesia (Y).

5. Secara parsial variabel aset berwujud (X4) berpengaruh terhadap kinerja keuangan pada CV. Tumarima Indonesia tahun 2018 (Y).

6. Variabel bebas leverage (X1) merupakan variabel bebas yang dominan mempengaruhi variabel terikat yaitu kinerja keuangan pada CV. Tumarima Indonesia tahun 2018

\section{Saran}

Mengacu pada hasil penelitian yang menunjukkan bahwa variabel bebas yang dominan mempengaruhi kinerja keuangan, maka hendaknya perusahaan selalu :

1. Menggunakan fasilitas dan peralatan terbaru ketika untuk menyiapkan masakan dan minuman

2. Selalu merenovasi bangunan dan fasilitas rumah makan ketika ditemui ada sedikit kerusakan untuk memberikan kenyamanan bagi pengunjung. Disamping itu perbaikan fasilitas dan ruangan yang lebih baru merupakan daya tarik tersendiri bagi pengunjung untuk kembali lagi

Hasil penelitian menunjukkan variabel pajak tidak berpengaruh terhadap kinerja keuangan pada CV. Tumarima Indonesia tahun 2018, maka hendaknya perusahaan :

Lebih meningkatkan ketepatan waktu dalam membayar pajak. Sebagaimana diketahui bahwa pembayaran pajak merupakan kewajiban bagi tiap badan usaha. Kelancaran dalam membayar pajak akan berpengaruh terhadap kemudahan pemerintah dalam memberikan perijinan usaha, 
pengurusan pinjaman ke bank dan lain - lian yang manfaat jangka panjang berpengaruh pula terhadap eksistensi perusahaan.

\section{REFERENSI}

[1] Mulyadi, Sistem Akuntansi, Edisi Ketiga., 3rd ed. Jakarta: Salemba Empat, 2001.

[2] F. Memon, N. A. Bhutto, and G. Abbas, "Capital structure and firm performance: A case of textile sector of Pakistan," Asian J. Bus. Manag. Sci., vol. 1, no. 9, pp. 9-15, 2012.

[3] I. Fahmi, Analisis kinerja keuangan, 3rd ed. Bandung: Alfabeta, 2012.

[4] P. D. S. Pitanatri, D. Z. Hamidi, R. Christianty, E. L. Lydia, and K. Shankar, "How data analytics and survey data is importent for the long term decision of business," J. Crit. Rev., vol. 6, no. 5, pp. 117-121, 2019, doi: 10.22159/jcr.06.05.20.

[5] B. Riyanto, Dasar-dasar pembelanjaan perusahaan, Edisi Keempat., vol. 59. 2001.

[6] M. A. Memon and I. M. Tahir, "Performance analysis of manufacturing companies in Pakistan,” Bus. Manag. Dyn., vol. 1, no. 7, p. 12, 2012.

[7] W. Tariq, I. Ali, H. M. Usman, J. Abbas, and Z. Bashir, "Empirical Identification of Determinants of Firm's Financial Performance: a Comparative Study on Textile and Food Sector of Pakistan," Bus. Econ. Res., vol. 3, no. 1, p. 487, 2013.

[8] M. M. Hanafi, Manajemen keuangan. Yogyakarta: BPFE UGM, 2004.

[9] E. Naryono, "Pengaruh transaksi derivatif terhadap likuiditas perekonomian di Indonesia 1999-2003,” 2013, [Online]. Available: repository.unej.ac.id.

[10] I. M. Pandey, Essentials of Financial Management, 4th Edtion. Vikas publishing house, 2015.

[11] W. Beaver, P. Kettler, and M. Scholes, "The association between market determined and accounting determined risk measures," Account. Rev., vol. 45, no. 4, pp. 654-682, 1970.

[12] S. Kallapur and M. A. Trombley, "The investment opportunity set: Determinants, consequences and measurement," Manag. Financ., 2001, doi: 10.1108/03074350110767060.

[13] E. F. Brigham and J. F. Houston, Fundamentals of Financial Management: Concine, Ninth Edition. 2016.

[14] H. Kaaro, "Financing Decision Relevancy: An Empirical Evidence of Balancing Theory," 2002.

[15] J. J. Gaver and K. M. Gaver, "Additional evidence on the association between the investment opportunity set and corporate financing, dividend, and compensation policies,” J. Account. Econ., 1993, doi: 10.1016/0165-4101(93)90007-3. 
[16] M. E. Porter, "Competitive Strategy Techniques for Analyzing Industries and Competitors : with a New Introduction," The Free Press. 1980.

[17] J. Hartono and D. Sulistiawan, "Performance of Technical Analysis In Declining Global Markets," SSRN Electron. J., 2014, doi: 10.2139/ssrn.2530411.

[18] S. C. Vogt, "Cash Flow and Capital Spending: Evidence from Capital Expenditure Announcements on JSTOR." https://www.jstor.org/stable/3666166?seq=1 (accessed Jan. 02, 2021).

[19] S. Kallapur and M. A. Trombley, "The association between investment opportunity set proxies and realized growth," J. Bus. Financ. Account., vol. 26, no. 3-4, pp. 505-519, 1999, doi: 10.1111/1468-5957.00265.

[20] C. W. Smith and R. L. Watts, "The investment opportunity set and corporate financing, dividend, and compensation policies," J. financ. econ., vol. 32, no. 3, pp. 263-292, Dec. 1992, doi: 10.1016/0304-405X(92)90029-W.

[21] A. Pangestuti, “ANALISIS IMPLEMENTASI MODEL Z-MIJEWSKI DALAM MEMPREDIKSI FINANCIAL DISTRESS PADA PERUSAHAAN PERDAGANGAN BARANG PRODUKSI (WHOLESALE) YANG TERDAFTAR DI BURSA EFEK INDONESIA," in PROSIDING SEMINAR NASIONAL HASIL PENELITIAN, Oct. 2019, vol. 2, no. 2, pp. 1577-1583, Accessed: Jan. 02, 2021. [Online]. Available: https://www.e-prosiding.umnaw.ac.id/index.php/penelitian/article/view/393.

[22] Kasmir, Analisis Laporan Keuangan, Edisi Satu, Cetakan Ketujuh. 2014.

[23] D. Z. Hamidi and E. Lisnawati, "Measuring the Feasibility of Urban Transport Business Operations in the Disruption Era: A Case Study in Sukabumi City,” 2020, vol. 417, no. Icesre 2019, pp. 37-42, doi: 10.2991/assehr.k.200318.007.

[24] R. Zeitun and G. Tian, "Capital structure and corporate performance: evidence from Jordan,” Australas. Accounting, Bus. Financ. J., 2007, doi: 10.14453/aabfj.v1i4.3.

[25] C. Izati and F. Margaretha, "Faktor-faktor yang mempengaruhi kinerja keuangan pada perusahaan Basic Industry and Chemicals di Indonesia," E-journal Manag. Fak. Ekon. Univ. Trisakti, vol. 1, no. 2, pp. 21-43, 2014.

[26] L. J. Gitman and C. J. Zutter, Principles of Managerial Finance 14th Edition. 2015.

[27] F. Margaretha and A. R. Ramadhan, "FAKTOR-FAKTOR YANG MEMPENGARUHI STRUKTUR MODAL PADA INDUSTRI MANUFAKTUR DI BURSA EFEK INDONESIA," J. Bisnis dan Akunt., vol. 12, no. 2, pp. 119-130, 2010, doi: 10.34208/JBA.V12I2.191.

[28] J. Joni and L. Lina, "Faktor-faktor yang mempengaruhi struktur modal," J. Bisnis dan 
Akunt., vol. 12, no. 2, pp. 82-97, 2010.

[29] R. Zeitun, G. G. Tian, and S. Keen, "Macroeconomic determinants of corporate performance and failure: evidence from an emerging market the case of Jordan," Corp. Ownersh. Control, vol. 5, no. 1, pp. 179-194, 2007, doi: 10.22495/cocv5i1c1p2.

[30] Budi Rahardjo, “Laporan Keuangan Perusahaan,” Budi Rahardjo, 2009.

[31] I. R. Akintoye, "Effect of capital structure on firms' performance: The Nigeria performance,” Eur. J. Econ. Financ. Adm. Sci., vol. 10, no. 10, pp. 233-243, 2008.

[32] Prof. DR. Sugiyono, "Pengantar Metodologi Penelitian Kualitatif," Metodol. Penelit. Kualitatif, 2009.

[33] I. Ghozali, “Aplikasi Analisis Multivariate dengan Program IBM SPSS 23," (Edisi 8). Semarang: Badan Penerbit Universitas Diponegoro, 2016. . 